\title{
A Literatura Norteamericana no Brasil
}

ongFellow foi muito popular no Brasil. Hoje será pouco lido, ou apreciado, como ocorre em tôda a parte. A geração a que êle pertencia e que êle cantava ao gôsto de todos, é de tempos mortos. Embora a sua popularidade na época, a crítica sôbre êle é muito escassa; mais correto fora dizer que quase não existe. ${ }^{24} \hat{E}$ certo que a sua voga no Brasil não se pode comparar - e muito menos ainda a influência exercida sôbre o brasileiro- com a que gozava na Colombia e nos países do Mar Caribe, como já indiquei no meu ensaio sôbre o assunto. ${ }^{25} E$ bastante um dado bibliográfico para demostrar até que ponto chegou, porém, a estima de Longfellow no Brasil: "Evangelina. Poema de H. W. Longfellow / Escolhido / pelo Conselho de Instrucção Publica / e approvado / por / Aviso de 11 de Julho de 1883 / Para exame da Lingua Ingleza na Corte e em todas as provincias do Imperio / Bahia/Litho-typographia de João Gonçalves Tourinho / 1883."

Mais uma vez é Afrânio Peixoto que ilumina o dado acima: "Fizemos mais: com ciumes talvez de escritores ingleses mais puros, de americanos de mais gênio, Poe ou Whitman, Longfellow foi autor preferido nos estudos e exames de humanidade: 'O velho relógio da escada,' 'Excelsior,' 'Psalmos da vida' . . andam nas memórias, desde colegiaes, consagrando o grande poeta popular da América." 26

A fama de Dom Pedro II como amante da nossa cultura e grande amigo dos Estados Unidos é bem conhecida. Talvez poucos saibam, todavia, que o monarca era também poeta e que no pequeno volume de seus versos, muitos, segundo dizem, que parecem espúrios, ${ }^{2 \tau}$ en- 
contram-se traduções de Whittier e de Longfellow feitas por êle mesmo. ${ }^{28} \mathrm{E}$ de fato, foi precisamente na corte de Dom Pedro em Petrópolis, e na sua presença, que o Barão de Loreto, Franklin Dória, em 1870 , leu a sua primeira versão de Evangelina, dedicada ao imperador. $\mathrm{Na}$ nota preliminar a esa tradução, publicada no Rio em 1874, o Barão afirma que a sua é a primeira tradução do poema para o português. Também se pode acrescentar que provavelmente foi Evangelina o primeiro poema norteamericano publicado em tradução portuguesa no Brasil. O tradutor revela que já sabia da existência de uma tradução chilena ${ }^{29}$ e de outra italiana ${ }^{30}$. Com respeito à sua, disse: "Antes quero que a tradıção seja uma cópia fiel e verdadeira, do que uma galante e floreada imitação... vertendo palavra por palavra, pude, se não me engano, mostrar que a nossa lingua não é sòmente [egual] à inglesa, antes como ela rivaliza em riqueza de vocábulos e variedade de tons."

Mas apesar do manifesto orgulho com que o Barão nos oferece a sua primeira versão, não ficon inteiramente satisfeito com ela. Anos. mais tarde, em 1909, saiu uma segunda edição, revista e corrigida, prova da larga convivência dêle com o nosso poeta, convivência e admiração recompensadas com várias cartas do próprio Longfellow, uma datada em Cambridge, 17 de abril de 1874, em que o poeta elogia a tradução, e outras em que agradece os exemplares a êle dedicados.

Para que o leitor tenha oportunidade de apreciar o êxito que coroou a devoção do Barão de Loreto à poesia de Longfellow, oferecemos aquí os primeiros versos da primeira versão, de 1870, e da. segunda. de 1909:

Eis aquí a floresta primitiva.

Murmurantes pinheiros e cicutas,

Lá, com barbas de musgo e vestes verdes,

Se elevam, no crepúsculo indistintos,

Quaes os druidas de outrora, com tristonhas

$E$ proféticas vozes; quaes harpistas,

Com alvas barbas que em seus seios poisam.

Das sáxeas cavernas perto o oceano

De voz profunda brada; e em tons sentidos

Lhe responde o lamento da floresta.

Eis aquí a floresta primitiva.

Murmurantes pinheiros e abetos,

Com as barbas de musgo e vestes verdes, 
Se elevam, no crepúsculo indistintos, Quaes os antigos Druidas com vozes Pesadas e proféticas, se elevam Quaes harpistas de outrora encanecidos, Com barbas que lhes caem sôbre o peito. Troante, das cavernas penhascosas O oceano, com a voz profunda, Vizinho fala; e em tons desconsolados Lhe responde o lamento da floresta.

Seria injustiça não mencionar os nomes de outros tradutores de Longfellow como Américo Lobo, Aurélio Pires, o Dr. Lucindo Filho, e especialmente o F. L. Bittencourt Sampaio. Este último foi tão grande admirador de nosso poeta que escreveu, além de comentários críticos, dois sonetos sôbre êle que incluiu na nota preliminar a sua tradução dos Pocmas da escravidão, publicada no Rio em 1884. Essa nota preliminar é interessante também pela sua apreciação do nosso poeta, a quem, disse, se pode chamar "impressionista":

"... canta o que todos vêm e não viram, fazendo o leitor sentir de princípio a fim tudo quanto se reflete no fino espêlho de sua alma inspirada. Longfellow tem o segrêdo de prender pela originalidade das imagens, pela escolha sempre nova e admirável do assunto, e por um cantar meio selvagem, meio civilisado, mas harmonioso e perfeito, que não lembra nenhum poeta do velho continente. Não te rias do meu entusiasmo pelo poeta dessa admirável república dos Estados Unidos da América."

Outros brasileiros e brasileiras teriam participado com Bittencourt Sampaio do mesmo lírico entusiasmo pelo poeta norteamericano que comoveu todo o Brasil daquela época. ${ }^{31}$

Parece incrivel que não existissem traduções de Poe em português até 1890, ano em que a Companhia Nacional Editora de Lisboa e Rio começou a publicar alguns de seus contos na "Biblioteca Universal Antiga e Moderna." Se uma pesquisa mais longa, porém, não descobrisse traduções anteriores a esta data, teriamos de concluir que o mundo de língua portuguesa estava satisfeito conhecendo o nosso maior contista através das extraordinárias traduçôes de Baudelaire, e mesmo as traduções espanholas que começaram a aparecer em 1858, inspiradas no esfôrço fecundo do poeta de Les fleurs du mal. Passouse o contrário no caso de Cooper, por exemplo, cujos romances $\theta$ piloto e $O$ derradeiro mohicano foram traduzidos para o português 
em París já em 1838, pouco depois de serem publicados em tradução espanhola - primeiro em Madrid no ano 1832, e em París, quatro anos mais tarde. Garnier iniciou a publicação de Poe em português com a primeira coleção das Novelas extraordinárias em 1903; mas realmente não foi até a segunda década do século atual que Poe se fez mais popularmente conhecido em tradução portuguesa. E grato notar que, de 1925 para cá, treze coleções diferentes de seus contos e poesias foram publicadas, sendo a mais notável as Obras completas traduzidas por Oscar Mendes e Milton Amado e publicadas pela Casa Globo em 1944, como homenagem à memória de Poe e que recompensa em parte o silêncio e o descuido anteriores.

E mais escassa ainda a crítica sôbre Poe no Brasil, que até o momento atinge apenas a dez artigos, na maioria curtos e de pouca originalidade. É interessante observar que, com excepção do melhor dêles -o estudo de Agrippino Grieco que apareceu cerca de 1933seis outros foram escritos desde 1939. Uma olhadela nas fichas sob "Crítica" de Poe revela aliás que seis dos artigos quase nada contribuem para uma verdadeira apreciação do poeta. Araripe Júnior menciona Poe só uma vez no estudo intitulado "Estética de Poe," publicado em seis números da Revista brasileira, de 1895 a 1897 ! ${ }^{32}$ A contribuição de Mário Brant é apenas um artigo biográfico, como homenagem expressa ao centenário do nascimento de Poe; mas, há que confessá-lo, o artigo alcançou grande aceitação por ter sido publicado com bôas ilustrações na revista popular Kosmos. As notas (1939) de Orvácio Santamarina são de natureza biobibliográfica e a apreciação é subjectiva e fortemente influida pela crítica francesa.

As três "Páginas do galo branco" de Augusto Frederico Schmidt oferecem quatro impressões dos Estados Unidos, uma das quais é fruto da leitura duma carta de Poe ao amigo George Eveleth - traduzida em português por Manuel Bandeira e publicada numa coleção de cartas célebres. Neśsa carta Poe justifica o seu abuso de bebidas em virtude do estado de insônia de que foi acometido quando da morte de Virgínia. Convem repetir um trecho do que diz Schmidt sôbre nosso bardo:

"A América estava verde demais para a presença de Poe... no entanto - não obstante o que se diz do seu exótismo, há qualquer coisa no seu gênio que só poderia vir a superfície graças à espécie de civilisação que a América viria revelar ao mundo. Nêsse 
sentido, Poe é tão representativo como o próprio Walt Whitmann (sic), bem pouco compreendido também.

O que Baudelaire, Mallarmé e outros grandes espíritos europeus ... sentiram na obra de Poe... foi sem dúvida êsse lado novo próprio da América, e que vem do homen ser o contemporâneo da técnica e não mais velho do que ela. Há em Poe um modo (não construido nem prevenido) de ver as coisas que é o mesmo, no plano desinteressado e puro do espírito, que iria dar o sentido da criação material do mundo norteamericano.

O Poe homem de ciência, quer dizer o homem capaz de viver os conhecimentos científicos e possuir naturalmente uma noção matemática das coisas, é um ser, uma alma, uma personalidade diferente de um Pascal, em cujo gênio prodigioso a angústia se configurou e está representada para sempre." 33

A essência da posição de Manuel de Abreu em relação aos nossos dois grandes poetas ${ }^{34}$ é perceptível no trecho citado nesta Bibliografia sob Whitman, "Crítica", e do qual interessa repetir aquí o seguinte:

"Vivesse Poe nêste momento (1943), êle veria no nazifascismo a última fantasia do tenebroso inimigo de outrora e teria escrito uma nova série de histórias extraordinárias que Jorge de Lima verteria para o desconhecido esplendor do português."

E o artigo de Casimiro da Silva é apenas uma coleção de observações sôbre facêtas distintas e desconexas da vida e da obra de Poe. Comenta a aspereza da crítica literária de Poe, achando que essa "indefinivel sensação da injustiça das coisas," de que falou Longfellow, constitue o traço predominante do seu caráter - "do gênio que só podia tolerar gênios, que não admitia gradações de inteligência." Termina por confessar que para êle Poe é "uma simbiose desconcertante de Baudelaire, filósofo bramane e Hoffmann." 35

Lúcio Cardoso, Oton M. Garcia e Agrippino Grieco mostram melhor compreensão de Poe. Lúcio Cardoso "vê em Poe "um homem cujo ser esteve perpètuamente dividido em dois, não por simples sentimentos antagônicos... mas visceralmente dividido em partes. irreconciliáveis, inimigas e desconhecidas entre si." Esclarecendo ainda. mais a sta concepção, diz que "através da história e da literatura conhecemos alguns homens de duas vidas, mas de dois seres diferentes numa só vida, sabemos de poucos exemplos." Analisado assim o gênio de Poe, não nos surpreende aquela famosa frase: "Eu não" 
podia anar senão onde a morte misturava seu sôpro ao da beleza," que define a sua teoria poética onde os extremos se misturam - a beleza e a moite. Para Lício Cardoso, pois, "estamos frente a uma das mais dramáticas e dolorosas histórias que o destino literário já escrevetı nas stas páginas" e frente também ao "primeiro poeta americano que vislumbra o mistério existente no homem e os abismos que o corroem." Lamenta que o nome de Poe fosse equiparado ao dos narradores de histórias macabras e que sua fama dependesse do fato de ter sido o criador do chamado romance policial. Lúcio Cardoso considera Poe um “dos maiores poetas da língua inglesa," e é do poeta que fala porque sente que a poesia o revela melhor do que os contos. Fixa maior atenção sôbre o artista genial que "tão profundamente cantou o 'Idolo chamado Noite'," o sonhador de Berenice, de Lenora, de Morella, e de Virgínia Clemm - "A derradeira encarnação do seu sonho."

Por último, merece ser repetida a explicação que oferece o crítico brasileiro sôbre a tragédia de Poe, Poe que foi "o prineiro sintoma de uma revolta ... o primeiro grito contra esta terra que de tão forte ousa se impor como mais poderosa do que o homem".

"Se passearmos êste sombrio pocta que não sabia reconhecer a beleza sem o sôpro da morte, na colméia ativa e interessante que tôda a nação americana representava naquêle tempo, compreenderemos perfeitamente bem o seu horror pela lenda do progresso, pela falta de gôsto generalizado, pela idéia moderna e social do homem máquina, por todo êste complicado mecanismo gerado para trucidar o Poeta e o seu sonho de unidade."

Afirmando que a literatura norteamericana "parece uma sucessão de aspectos coerentes," Oton M. Garcia ${ }^{37}$ admite que Poe, todavia, romântico a seu modo, "é uma expressiva singularidade no nosso cenário literário, sem lugar nem espaço definidos." Insiste na originalidade de Poe, "refratário a correntes ou a movimentos," manifestando assim a sua discordância com os que o acusam de plágios: "O que pudesse haver de assimilado no seu espíritu criador não teria sido o resultado de um trabalho consciente, mas o resíduo inevitável de uma herança cultural." A seguir, baseandose nas palavras de Parrington no livro Main currents in American thought: "His romanticisms were of quite another kind than those his countrymen were pursuing," pretende defender sua tese sôbre "Poe -- anti-romântico." Bem po- 
dem ser ficções do romantismo a atitude rebelde do Poe iconoclasta e certos temas e sentimentos de sua arte, "mas se formos caracterizar a forma de expressão dêsses sentimentos, encontrariamos que o tratamento de Poe difere muito do de seus contemporâneos." O que há em Poe, e não é dos românticos, identifica-o melhor com os parnasianos - com Baudelaire por exemplo - do que com os românticos : "A escolha de muitos temas prediletos dos parnasianos, a linguagem plástica, o uso de termos concretos, a evocação do passado, a sinfonia vocabular, a rima rebuscada... a correção gramatical, que denota sua intenção de escrever bem —como um clássico- esculturalmente bem - como os neo-clássicos ou parnasianos." $\mathrm{Na}$ prosa, "quer na escolha do assunto quer na composição das cenas quer ainda na apresentação e condução das personagens, Poe é indubitàvelmente original e precursor." Lúcio Cardoso e Oton M. Garcia coincidem às vêzes numa atitude simpática e concepção penetrante em relação ao nosso poeta, mas isto apenas contribue para melhor apreciação dos seus valiosos trabalhos que tão bem se complementam.

E com facilidade que o combativo crítico Agrippino Grieco ${ }^{38}$ se mostra capacitado para falar mais autorizadamente da personalidade, da obra e da influência do nosso poeta, que cometeu uni delito ainda não perdoado por seus conterrâneos: "o delito de 'bien écrire', escândalo de todos os ruminadores de versículos bíblicos de Boston, Chicago e análogas Porcópolis..." Conhece, en primeira mão, a longa história da sorte e da influência de Poe na Europa, especialmente na França, na Inglaterra, e na Itália, referindo-se a Baudelaire, Maeterlinck, Mallarmé, Verlaine, Wilde, Papini, entre muitos outros. Como exemplo duma influência mais recente de Poe sôbre a moderna poesia francesa, afirma que Poe "viu a significação da poesia pura muito antes de Valéry, dêsse Valéry que o adora:" Também sabe do poeta traido pelos seus próprios patrícios. Fustiga Griswold, tacha Woodberry de "frígido professor", cuja critica foi "desprovida daquela simpatia sem a qual não há crítica possivel," a conclue, não sem justiça, que sendo "inimigo da zoocracia mercantil," Poe foi sempre mais querido entre latinos que entre anglosaxônios." Conhece, e parece ter estudađo bem, as mais célebres traduções francesas do "Corvo," como também as italianas e as portuguesas. Vamos transferir uma discussão do seu comentário sôbre estas últimas até falarmos delas mais adiante. No momento, é bastante observar que Grieco referese a tra- 
dutores e críticos de Poe, no Brasil, sem dêles acrescentar, desgraçadamente para nós, os desejados dados bibliográficos, impossibilitandonos assim, em alguns casos, de citar-lhes os trabalhos na Bibliografia. Seria interessante, por exemplo, saber quem foi o médico, ex-deputado e membro da Academia de Letras, autor do artigo que estropia sistemáticamente o nome de Poe de começo a fim e "pespega nas costas de Poe agonizante um cartaz de partido político." Comenta então o formidável satirista e crítico brasileiro: ". . . ao lê-lo vendo-o aludir com piedade à loucura do poeta do 'Corvo', não sabemos bem qual seja, no caso, o maluco, e se aí não há uma inversão de papéis." Se a Poe assim se refere um Acadêmico, somos levados a acreditar com Grieco que Poe nunca foi muito divulgado no Brasil e que dêle "só se tem visto o lado fantasmático...," o especialista do macabro. Grieco quer pôr en relêvo o lado ideológico do "finíssimo americano" que "lançou na literatura uma perfeita ideologia estética, sem que se possa verificar ao certo onde... se alonga a linha divisória ... entre a razão e a loucura." Quer salientar também que Poe foi o "precursor da clínica de moléstias mentais" e até autor de um lindo ensaio sôbre a técnica dos jardins e sôbre a ciência do mobiliário, procurando ornar "o mais inestético dos países e dar o sabor dos ambientes decorativos ao mais grosseiro dos povos..." 39

Mas é Poe o poeta que Grieco mais admira. Poe, Emerson e Whitman são os nossos maiores poetas, "ao lado dos quais Longfellow e Bryant não passam de rimadores secundários." Os versos de Poe são "transposições do real no irreal . . . batidos de uma claridade quimérica, de nimbos e limbos, con algo de meteórico, de lunar, de boreal." Clasifica-o como "espírito romântico e escritor clássico" que, contemplativo e noturno por excelência, "preferia as lâmpadas ao sol." Considera que o poema, "Os sinos, é sem dúvida a mais bela melodia de sílabas de que se pode ufanar a língua inglesa." "O corvo" ocupa o melhor de sua atenção. Não faz questão das fontes atribuidas ao poema, "que pouco significam para arrancar ao escritor americano o seu achado poético." Conta a história da sua recepção e repassa as discussões sôbre a "Gênese" que chama "obra de quem era contra a concerto romântico do binômio gênio-desordem ... uma represália estética" motivada por "fleuma e 'spleen' que levavam-no a assim divertir-se com os zoilos e os foliculários ..." A caracterização que faz de Poe através da sua obra prima é, pelo menos, original: "No 'Corvo," 
melhor que em outros trabalhos seus, vê-se bem o iluminado algo sarcástico, o poeta bilioso nascido entre comerciantes sanguíneos, o alegorista afeito a impor-nos as suas visões tirânicamente, arrastandonos a tôdas as voragens, precipitando-nos, sem defensa, em todos os maelstroms do espírito. As vêzes, um excesso de lucidez, um requinte de sagacidade, quase que o torna odioso a nossos olhos." "O corvo," segundo Grieco, é um "incomparável diálogo filosófico, que é, por assim dizer, o monólogo de 'Hamlet' a duas vozes."

Grieco conclue o seu estimulante ensaio com. êste belo tributo ao "maior dos poetas americanos":

"As mulheres que amam Poe devem ser mais delicadas no amor e os homens que o amam enxergam nêle o verdadeiro mártir moderno, o Santo leigo que ajudando-os a entrar no Reino da Beleza, bem pode também ajudá-los a penetrar no Reino dos Céus. Poe é o ponto de encontro de tôdas as almas belas, amá-lo ou detestá-lo é definir-se."

Os críticos concordam em que no Brasil "só se tem visto o lado fantasmático" de Poe. O poeta é conhecido apenas através do "Corvo" na tradução de Machado de Assís, que, nas palavras de Agrippino Grieco, "será apenas para os nossos declamadores de ambos os sexos un recitativo de efeito, com tremores vocais à chegada do patético estribilho." Uma passada d'olhos na Bibliografia revela que nenhuma das primeiras coleçóes de contos em tradução portuguesa contem prefácio ou prólogo que proporcione dados biográficos sôbre Poe. A primeira de que tenho notícia é a coleção publicada pela Empresa Editora Rochera em 1925 e que traz na página titular êste precioso aviso dos editores que querem capitalizar no aspecto macabro de Poe:

"Leitura pouco recomendável às pessoas de espírito fraco: meninos histéricos, jovens acéfalos, velhos cardíacos, matronas beatas e outros que creem em almas do outro mundo e cousas inverosíneis."

Segtiramente essa nota foi parte da tática de publicidade para acelerar a venda do livro como também a referência à famosa frase de Doyle: "Se Poe nunca tivesse escrito 'O duplo assassínio na Rua Morge' [e êsse é o título da coleção!] é provável que eu também nunca viesse a crear Sherlock Holmes." Mas apesar da sensacional propaganda, os editores não publicaram as obras completas de Poe 
como haviam prometido fazer no caso do público gostar dêsse primeiro volume! Também é interessante observar que a breve nota biográfica repete os mesmos êrros universalmente divulgados por Baudelaire e continuados pela maioria dos autores brasileiros de prólogos. Assim, pois, até os nossos tempos, no Brasil, Poe era conhecido quase que exclusivamente como contista "de assombros e espantos," ao passo que os escassos dados sôbre a sua vida vieram diretamente de Baudelaire. Realmente a única excepção de importância é a edição das obras completas publicada pela Casa Globo em 1944. Esta traz, como informação sôbre a vida de Poe, a "Notícia biobibliográfica" escrita por Hervey Allen em 1927, e como exemplo da apreciação europea de Poe, o célebre estudo por Baudelaire.

Sôbre as traduções da prosa de Poe para o português só temos a confirmar que quase tôdas, especialmente até 1930, são traduções da tradução de Baudelaire, "pađecendo dos mesmos defeitos, êrros, omissões e incompreensões, que infirman por vêzes aquela." ${ }^{40}$ Cumpre chamar novamente a atenção para a excepção mais notável: Oscar Mendes e Milton Amado tiveram de trabalhar quase que únicamente com "recursos próprios," sempre do original, mas no caso da prosa aproveitando a trađução de Baudelaire, e no caso da poesia, cotejando a tradução em prosa de Vitor Orban e a tradução em versos de Carlos Obligado. Ambos fizeram a tradução da prosa; a parte das poesias, porém, coube exclusivamente a Milton Amado.

"O corvo" foi a primeira poesia de Poe a ser traduzida em português. E difícil determinar quem fez a primeira tradução, se Machado de Assís ou Américo Lobo. Por não haver sido publicada anteriormente, a versão daquêle só veio a lume na edição das suas Poesias completas, impressas por Garnier en 1901, ao passo que a de Américo Lobo apareceu pela primeira vez no Jornal do comércio do Rio, 7 de agôsto de 1892. ${ }^{41}$ Tenho conhecimento de pelo mesmo oito traduções diferentes do poema. A mais divulgada e a mais popular é a de Machado de Assís.

Os únicos outros poemas traduzidos mais de uma vez foram "Os sinos," "Annabel Lee," e "Eldorado." Dos demais só existem as traduções de Milton Amado. O mundo português teve de esperar até 1944 afim de poder apreciar tôda a produção poética de Poe na obra monumental da Casa Globo. 
Como no caso das trađuções do "Corvo" em espanhol, as últimas em português também são superiores, mais literais e ao mesmo tempo mais literárias. Agrippino Grieco estudou várias cuidadosamente, e é interessante o que tem a dizer a respeito delas. Alude a uma crítica favorável duma bôa tradução do poema feita por um patrício, mas não esclarece "quem" ou "quando." Não pode ser a de Américo Lobo, que nos parece das menos inspiradas. Será talvez a tradução de João Köpke, da qual não tenho o menor indício, salvo informação verbal. ${ }^{42}$

E mais provável que Grieco refira-se à versão de Gonđin da Fonseca que foi publicada pela primeira vez juntamente com as suas trađuções dos "Sinos" e "Annabel Lee," numa edição particular e primorosa, cerca de 1930. Esta sim, é uma tradução fiel, poética, e das mais felizes. Da tradução pela portuguesa dona Mência Mousinho de Albuquerque, que não conheço, Grieco diz que é "literal mas pouco literária, talvez infiel porque fidelíssima." Interessame duplamente poder estudar a tradução de Emílio de Menezes, "o último boêmio," -mencionada e comentada já por muitos mas cujo texto ainda me falta- pelo contraste entre as opinóes emitidas por Grieco e por Elysio de Carvalho sôbre o valor da mesma. Grieco chama-a uma "imitação" em sonetos, "aquêlẹ sonetos que desejavam ser de mármore e eram apenas de cimento armado, a pior parte do legado do maior dos nossos satíricos e do mais artificioso e fatigante dos nossos líricos. Essa variante justifica o espirituoso epigrama do Sr. Mário de Andrade quando diz: 'Emílio de Menezes injuriou a memória do meu Poe...' E é traição literária..." ${ }^{43}$ Elysio de Carvalho vai ao outro extremo:

"Emílio de Menezes para ser grande bastava que tivesse dado à nossa literatura a tradução do $O$ corvo de Edgar Poe... [que] segundo uns, vale o original ... segundo outros, excele o poema do poeta americano. Quem ler a tradução de Emílio, assombro de expressão e de fôtça, confrontando com o original, verá, efectivamente, que, da obra prima de Poe, êle fez um extraordinário poema em nossa língua que, me parece, projecta certa claridade mística sôbre o profundo, o vago, o nebuloso simbolismo do texto, produzindo o mesmo efeito que a luz clara do sol quando banha os velhos vitraes das catedraes góticas. Não é uma tradução: é a espiritualisação do enigma." 44 
E, por último, vejamos o que Grieco pensa do trabalho de Machado de Assís :

"A peça do nosso Machado, aproveitando-se visivelmente do 'Corbeau' de Baudelaire, é antes paráfrase que tradução, saborosa poesia de bom prosador, ou seja uma linda prosa, viva e flexível, agradável sempre, mas despreocupada da literalidade, suprimindo coisas, modificando outras, agindo sempre com libérrima desenvoltura. Um bom trabalho, de um homem de talento que, embora o quisesse, não saberia fazer nada de mediocre, mas encerrando algumas impropriedades desconcertantes como 'tranças angelicais,' e malentendidos inexplicáveis, qual a mundança de uma lâmpada em lampeão, na última estrofe. Além do mais, um tanto prolixa, alongando cento e oito versos em cento e oitenta. Mesmo a diversidade de metros, se serve para facilitar o recitativo, tira o efeito de soturnidade que é um dos segrêdos do 'Corvo.' Tudo muito realista em nosso parafrasta e sem nada daquela doçura, opiada, visionária, que faz de Poe un tecedor de árias de sonho." 45

Para que o leitor tenha oportunidade de estudar algumas estrofes da tradução de Machado de Assís afim de avaliá-las — segundo o critério de Grieco- e compará-las com algumas outras, tôdas recentes e tôdas mais literais e mais fieis que aquela, oferecemos aquí a primeira, terceira, e última estrofes de Machado de Assís, Gondin da Fonseca, Milton Amado, e Emílio de Adour. A seleção das mesmas é mais ou menos casual; não foi minha intençã่o escolher as que, na minha opinião, representam a melhor realização de cada um:

Em certo dia, à hora, à hora

Da meia noite que apavora,

Eu, caindo de sono e exhausto de fadiga,

Ao pé de muita lauda antiga,

De uma velha doutrina, agora morta,

Ia pensando, quando ouví a porta

Do meu quarto um soar devagarinho

E disse estas palavras taes:

"É alguen que me bate à porta de mansinho;

"Há de ser isso e nada mais."

E o rumor triste, vago, brando

das cortinas ia acordando

Dentro em meu coração um rumor não sabido

Nunca por êle padecido.

Emfim, por aplacai-o aquí no peito, 
Levantei-me de pronto, e: "Com efeito, (disse) é visita amiga e retardada

"Que bate a estas horas taes.

"E visita que pede a minha porta entrada:

"Há de ser isso e nada mais."

E o corvo aí fica; eil-o trepado

No branco mármore lavrado

Da antiga Pallas; eilmo imutável, ferrenho.

Parece, ao ver-lhe o duro cenho,

Um demonio sonhando. A luz caida

Do lampeão sôbre a ave aborrecida

No chão espraia a triste sombra; e fóra

D'aquelas linhas funeraes

Que flutuam no chão, a minha alma que chora

Não sai mais, nunca, nunca mais!

\section{Machado de Assis (1901 ?)}

Certa vez quando, à meia noite, eu lia, fraco, extenuado, um livro antigo e singular, sôbre doutrinas do passado, meio dormindo, - cabeceando, - ouví uns sons, trémulos, taes como se leve, bem de leve, alguém batesse a minha porta.

"É um visitante", murmurei, "que bate, leve, a minha porta.

"Apenas isso, e nada mais."

E das cortinas côr de sangue, o arfar soturno, e brando, e vago, causou-me horror nunca sentido, - horror fantástico e presago. Então, fiquei (para acalmar o coração de sustos taes) a repetir: "E alguém que bate, algućm que bate a minha porta; "algum nocturno visitante, aquí batendo a minha porta;

"é isso!, é isso e nada nais!"

E não saiu! e não saiu! Ainda agora se conserva pousado, trágice e fatal, no busto branco de Minerva.

Negro demônio sonhatior, ons olhos são como punlaes!

Por cima, a luz, jorrando, espalha a snmbra dêle, que flutua... $\mathrm{E}$ a alma infeliz, que me tombou dentro da sombra que flutua não ha de erguer-se, - nunca mais!

Gondin da Fonseca (1930 ?;

Foi uma vez: eu refletia, à meia-noite êrma e sombria, a ler doutrinas de outro tempo em curiosíssimos manuais, e, exhausto, quase adormecido, ouví de súbito um ruído, tal qual se houvesse alguém batido a minha porta, devagar. "Ê alguém" - fiquei a murmurar- "que bate à porta, devagar; sim, é só isso e nada mais." 
A sêda rubra da cortina arfava em lúgubre surdina, arrepiando-me e evocando ignotos mêdos sepulcrais.

De susto, em pávida arritmia, o coração veloz batia e a sossegá-lo eu repetia: "E um visitante e pede abrigo.

Chegando tarde, algum amigo está a bater e pede abrigo.

$E^{\prime}$ apenas isso e nada mais."

E lá ficou! Hirto, sombrio, ainda hoje o vejo, horas a fio, sôbre o alvo busto de Minerva, inerte, sempre em meus umbrais. No seu olhar medonho e enorme o anjo do mal, em sonhos, dorme, e a luz da lâmpada, disforme, atira ao chão a sua sombra. Nela, que ondula sôbre a alfombra, está minha alma; e, presa à sombra, não há-de erguer-se, ai! nunca mais!

Milton. Amado (1944)

Certa noite, acabrunhado, meditava eu, já cansado,

Sôbre estranhos alfarrabios, suas lendas, seu passado,

Quando - a cabecear de sono - ouví pancadas desiguais,

Como se, de leve, houvesse alguém batendo a minha porta;

"E visita" - murmurei - "que está a bater a minha porta, Isto só, e nada mais."

E o ondular, sedoso e langue, das cortinas côr de sangue, Me excitou, me encheu de horror desconhecido, e pôs-me exangue,

Tanto que eu, para acalmar meu coração de ânsias letais,

Repetia: - "Uma visita que me vem bater à porta -

E' visita retardada que me está a bater à porta;

Isto, sim, e nada mais."

$\mathrm{E}$ o maldito não se importa, não se move ou se transporta

Do meu busto, alvo, de Pallas, encimando a minha porta;

$\mathrm{E}$ os seus olhos - aos de um demo que sonhasse - são iguais;

E da luz um feixe intenso the projeta a sombra ao clıăo;

E minha alma, desta sombra que flutua, alí, no chão; não se livra nunca mais!

Emílio de Adour (1945)

Tá adrertí que as posibilidades de julgar diversas traduções de determinadas poesias de Poe são infelizmente limitadas. Aliás, o espaço não nos permite dar exemplos nêste trabalho de algumas das versões mais felizes, felizes, segundo Grieco, a despeito de que, "acentuando como acentuam as dificuldades de trasladar ao português," a lingua de Camões é "língua de prosa e não de poesia!" Porém, é dé mais estrita justiça aplaudir o esfôrço titânico de Milton Amado que 
se atreveu a trasladar para uma língua tão ingrata senão uma mas tôdas as reconhecidamente difíceis melodias de Poe! E foi tarefa que realizou em tempo mínimo e não labor a que se dedicasse com o carinho de convivência através dos anos como no caso de um Baudelaire. Vejam-se, por exemplo, as traduçôes de "Annabel Lee," de "Ulalume" e de "To Helen" ("Tua beleza, Helena, faz pensar") e até que ponto o português se presta para captar a música do lirismo inglês.

E indiscutivel que Poe teve influência no Brasil, fato aliás atestado por Grieco, ${ }^{46}$ Putnam ${ }^{47}$ e Afrânio Peixoto. ${ }^{48}$ Mas ao contrário do caso Poe nos países de língua espanhola, ${ }^{49}$ não nos parece possível provar que Poe inspirasse relevante e decididamente qualquer grupo de escritores, escola ou movimento literário como o fizera na América espanhola durante a época modernista dos anos 1888-1914. E pela falta ou inaccessibilidade de coleções de obras poéticas e de publicaçóes periódicas é quase impossível tentar historiar essa influência desde as primeiras manifestações de interesse em Poe até o momento de seu triumfo, nos últimos vinte anos, com as traduçôes de seus poemas. Por isso, temos a nos contentar com dados sôltos sôbre autores individuais e até de distintos periodos.

Indubitavelmente Putnam não erra em afirmar que Poe tivera influência direta sôbre Alvares de Azevedo e seus correligionários da escola brasileira romântica e sepulcral dos ' 50 e '60 do século passado. Mas provas irrecusáveis quase não existem na poesia da época. Eram espiritos fraternais sim, e havia, realmente, reminiscências poeianas na obra de muitos dêles. As vêzes ocorre, porém, repetindo o caso da América espanhola, que as reminiscências recordam também certos europeus da época, Hoffmann, Heine, Baudelaire, cuja arte tem muito em comum com a de Poe. E êstes mesmos tiveram também marcada influência sôbre os românticos e post-românticos brasileiros. Agrippino Grieco reflete essa incerteza sôbre as possiveis fontes literárias dos românticos quando diz que Alvares de Azevedo levou, na Noite na taverna, "Poe e Hoffmann à Pauliceia...,", e quando comenta sôbre o nome da famosa taverna chamada "O corvo" frequentada por Azevedo e os demais boêmios paulistas daquêle tempo: "talvez influência de Poe ou arremedo do Bairro Latino na Piratininga meio civilizada de 48-51." 50 
E natural que os parnasianos e os simbolistas revelassem maior assemelhação a Poe. A poesia brasileira de 1880 em diante contem o suficiente para lembrar-nos dêle, Poe, seja na forma, nos assuntos e no espírito dos versos de poetas como Alberto de Oliveira (18571937), Coelho Netto (1864-1934), Emílio de Menezes (1867- ' ), Emmanuel Guimarães (1871-1907), Guilherme de Almeida (1890-

), e Eduardo Guimarães. Vejamos, rápidamente, em que consiste esta aparente assemelhação a Poe. No caso do mais "clássico" dos parnasianos brasileiros, Alberto de Oliveira, não é tanto questão de espírito e de assunto como de forma. Há poesias como, por exemplo, "O himno das chamas" que parecen denunciar uma imitação direta da métrica do "Corvo" e dos "Sinos." ${ }^{51}$ Coelho Netto, como poeta, revela-se espírito fraternal de Poe. A estrutura e os temas de muitos de seus versos fizeram que Goldberg visse nêles a possível influência de nosso poeta. ${ }^{52}$ Como tradutor de Poe, Emílio de Menezes patenteou sua admiração pelo autor do "Corvo." Não há nada na forma, porém, que mostre tal admiração, mas há mutito nos temas e no tom da poesia de Menezes que parece concretizá-la. O que diz Elysio de Carvalho a respeito da poesia de Menezes pode bem ser aplicado, em termos gerais, aos versos de Poe:

"A sua poesia, evocando alegrias extintas, ânsias desatinadas, dores convulsas, epilépticas, macabras, e cheia de dobres pungentes, vertigens mortuátias, terrores e pitoresca demência, ora desperta em nos um estado de sensório há longo tempo sepultado nos limbos do olvido, ora provoca a amarga nostálgia de outra forma de ser, de outra essência perfectibilisada que não mais volta..." 53

Emmanuel Guimarães (1871-1907), poeta e prosador, amante da música e tradutor de poetas como Dante e De Vigny, pertence também à mesma escola poética de Poe. Não nos dá oportunidade de afirmar que as aparências sejam fruto legítimo de sua admiração por Poe; mas inegavelmente poeianos são o espírito melancólico e desesperado ("Nunca mais voltarás? Nunca mais!"), os temas (amor perdido), e a forma (v. "Os vãos lamentos") de muitos de seus poemas. ${ }^{54}$

É provável que Poe tivesse exercido influência também sôbre Guilherme de Almeida (1890- ）, que, aliás, mostrou-se interessado na poesia estrangeira como tradutor de Géraldy, Tagore, et al. Como 
amostra de tal influência, leia-se, por exemplo, seu poema "O momento do amor" "55 que recorda instantâneamente a forma e o tom dos "Sinos." Os "Sinos" terão inspirado muitos poetas luso-brasileiros _cuja obra é para mim ainda quase desconhecida- como afirma Agrippino Grieco ao falar de Manuel Bandeira da seguinte maneira:

"Muita coisa deve também o Sr. Bandeira a Antônio Nobre. Ouvindo, no autor patrício, a angustiosa monodia dos sinos, comovemo-nos, mas muito mais nos comoveriamos ainda se a nossa memória... não recordasse certa monodia análoga do autor de "Só, que, aliás, já se teria inspirado em Poe..." 56

Muito mais abertamente discípulo de Poe é o simbolista Eduardo Guimarães, autor de traduçôes inéditas de Heine, Baudelaire, Verlaine, Hearn, e autor também de Históricus estranhas, ainda não publicadas em 1944. Há muito no seu livro $A$ divina quimera (Globo, 1944) que bem se poderia atribuir a Poe, e sem reservas, em vista do poeta confessar tal inspiração na escolha da célebre frase "Psyche, my soul," como lema da poesia intitulada "Prelúdio."

Sim, incontestavelmente para o brasileiro Poe é "o maior artista americano" 57 e aquêle que mais extensa influência teve no Brasil, influência que començou na época de Alvares de Azevedo e que encontra eco ainda hoje na memória de Tristão de Athayde e seus contemporâneos ${ }^{58}$ que na sua boêmia despreocupada recitayam "nostalgicamente" os versos "Bem me lembro, bem me lembro, foi no glacial Dezembro", na tradução do querido mestre Machado de Assís.

Emerson conta com dois nomes célebres entre os seus admiradores no Brasil: Tobias Barreto e Elysio de Carvalho. Já me referí ao artigo de Barreto, datado de 1886, no qual evidencia seu conhecimento e alta estima de nossa literatura e de nossa vida material e intelectual. ${ }^{59}$ Mas vamos deixar que o crítico Sylvio Romero fale uma vez mais das predileções literárias do ilustre sergipano: "A Nation de New York era uma de suas leituras prediletas e os ensaios de Emerson uma de suas delícias." 60 Barreto apela repetidamente para o "grande americano," e também para Carlyle. Para êle, Representative men e Hero worship são quase que uma Biblia em que encontra sempre os versículos e as verdades que lhe servem como irrefutável confirmação de suas próprias idéias e convicções. Percorre todo o panorama humano do Brasil para concluir: "Parece duro afirmá-1o, mas é verdade: nos não temos, entre nos não fulguram os Represen- 
tative men... de Emerson." " 11 Comentando a falta "de uma verdadeira eloquência parlamentar no seu país, aplaude Emerson quando êste se refere a um discurso como "um acontecimento histórico." 62 $E$ finalmente, acha adequadas até as imagens e as palavras do nosso filósofo quando com elas ilustra a observação que faz no ensaio "A influência do salão na literatura":

"A guerra, a política, os partidos, a ambição, o luxo, a moda, diz Emerson em sua linguagem imaginosa e poética, tudo isto, são burros carregados de cestas cheias de flores e frutos, para o serviço da mesa do rei espirito." 63

Indubitàvelmente, um sério estudo comparativo demonstraria uma contribuição considerável de Emerson na formação intelectual do estimulante pensador brasileiro.

No ensaio "Minha formação literária," Elysio de Carvalho (18801925) confessa a sua dívida a Emerson, o que já suspeitávamos nas frequentes referências a êste através de tôda sua obra. Ao mesmo tempo assinala o que nêle mais o atrae: "Os meus educadores de sensibilidade, em filosofia, foram: o americano Emerson com os seus Representative men e os ensaios em que exalça a personalidade humana, a confiança em si mesmo..." ${ }^{44}$ Os outros foram Carlyle, Ruskin, Ibsen, Gener, e Gorki. E fácil verificar até que ponto Emerson influiu diretamente na evolução da estética literária de Carvalho. Veja-se, por exemplo, o ensaio "O problema da cultura," em que apela para Emerson e Stendhal na sua definição de cultura: "A cultura, como manifestação individual ... é a disciplina dos sentimentos e das idéias que se constata em Stendhal e em Emerson ..." 65 Insiste muito no papel predominante do indivíduo na cultura, citando as palavras de Emerson: "Cada um de nos é único," para ressaltar a verdade: "Tôda escola, pois, vem a ser um perigo para as inteligên. cias." " ${ }^{6}$ Concluiremos com outra citação do crítico brasileiro, que merece ser repetida aquí pela sua significação e porque serve para determinar a posição de Carvalho em relação à arte, posição, aliás, que êle toma também em relação a Emerson, Ruskin, Guyau, Tolstoi e outros: "A arte cuja essência verdadeira deve produzir uma emoção profundamente social é, em uma palavra, a manifestação mais completa, mais desinteressada, mais sincera e mais eloquente da vida coletiva passada através de vida individual." ${ }^{67}$ 
Emerson tem, pois, alguns ilustres discípulos no Brasil. Curioso é, porém, notar que sôbre êle só existe um estudo crítico de que eu tenho conhecimento. E o ensaio de Oton M. Garcia, publicado na Revista do Instituto Brasil-Estados Unidos em 1945. Bem documentado, com numerosas citações da obra de Emerson, é digno tributo à memória de nosso "anti-romântico." É justiça repetir aquí a comparação que faz entre Whitman, Poe e Emerson para demostrar sua compreensão e apreciação dêsses nossos três vultos literários:

"Ao contrário dos seus dois grandes contemporâneos -o bíblico Whitman e o personalísimo Poe, para quem a emoção era a essência mesma da vida e da arte- Emerson é um intelectual equilibrado e frio, um espírito de cultura, requintado e estranho aos conflitos e às paixôes humanas, alheio às tragédias íntimas que não se desenrolem em tôrno de questóes de moral ou de crença religiosa."

Para finalizar, de penetrante observação é a explicação de Afrânio Peixoto sôbre a recente preferência brasileira por Emerson, e não Carlyle:

"O filósofo e ensaista tem uma clientela extensa de todos êsses não profissionaes da filosofia que se aborrecem doutamente com os pedantes sistemas europeus, sínteses formalistas fechadas aos profanos e que a simplicidade de Emerson traduziụ democráticamente, para nos outros, nem dogmáticos nem sibilinos leitores. Não é a vulgarização da filosofia, o que seria mediocre, é a poesia das razões da vida, o que é excepcional." 68

O caso Whitman no Brasil é parecido à história de sua poesia nos países hispano-falantes da América: ${ }^{69}$ é indiscutivel que Whitman tem sido uma fôrça estética e ideológica de alto relêvo para as novas gerações brasileiras; mas a sua influência é difícil de definir ou catalogar; ${ }^{70}$ é um tanto intangível, mais sentida que manifesta e patente. Um crítico tão autorizado como Tristão de Athayde insiste, porém, na importância para o seu país desta fồrça whitmaniana: "Nos americanos devemos sempre pensar em. Whitman. Ele chocou outr'ora a nossa cultura de salão, o nosso paisagismo de jardim de inverno. Mas a medida que vamos tomando consciência de nossa posição no mundo, de nosso enraizamento, vamos também reconhecendo o que devemos a sua visão nova de América, a sua originalidade." 71 Outros citarão os nomes de Ronald de Carvalho, Felipe de Oliveira, 
Sérgio Milliet, Oswaldino Marques, Angusto Frederico Schmidt, Wellington Brandão, ${ }^{72}$ Pádua de Almeida, Mello Mourão, ${ }^{73}$ Rossine Camargo Guarnieri, ${ }^{74}$ como poetas diretamente influidos por Whitman ou como espíritos fraternais, "sensíveis ao seu gênio." No entanto é curioso observar que até o ano 1942 não havia uma só tradução de Whitman feita por brasileiro ; ${ }^{75}$ e além disso, até êsse mesmo ano de 1942, o Brasil mantem um silêncio quase sepulcral sôbre o "Gran Velho." 76 Em confirmação dêsse descuido temos a palavra e o apếlo de Aníbal M. Machado, que, no excelente prólogo ${ }^{77}$ da edição dos Cantos de Walt Whitman, selecionados e traduzidos por Oswaldino Marques e publicados por José Olympio em 1947, lamenta "o quase desconhecimento" da obra de Walt no Brasil e confessa que
"isso tem privado a nossa poesia de una seiva vital capaz de res- tabelecé-la da anemia que a ameaça e de reduzir-lhe as fugas repe- tidas para o misticismo religioso. Esta seiva whitmaniana traz uma composição continental que nos é mais nttritiva - por estar mais de acôrdo com o nosso psiquismo poético e a nossa situação de povo em crescimento- do que a dicção tradicional que tomamos aos por- tugueses. Não se trata aquí apenas de forma poética, é questão de substância lírica. Esta é agora em nos bem diversa daquela para a qual foram feitos os moldes lusitanos. O movimento modernista brasileiro quebrou êsses moldes mas quebrou-os demais, a ponto de quase perder o contato com o humano."

Corrobora a falta de traduçóes para o português quando indica que as citações que inclue generosamente no seu trabalho - citações aliás bem escolhidas e bem traduzidas - são o resultado do confronto com a versão francesa de Bazalgette, conferida com o original e com as traduções de alguns dos poemas mais característicos feitas por escritores franceses como Gide, Laforgue, Fabulet, e Larbaud.

A Bibliografia anexa testemunha a escassez de critica brasileira sôbre Whitman; mas o pouco que existe, é bom, escrito com amor e critério e, o que é mais importante, uma compreensão sentida da estética e da mensagem do poeta profundo e do profeta inspirado que se complementam em Walt. E natural que o Whitman apreciado pelo brasileiro de hoje, correspondesse àquêle Whitman que é para a humanidade, desde que esta o descobriu, perplexa e confusa ante a crise universal de nossos dias, o poeta que melhor cantou as promessas e esperanças do Novo Mundo. Para êle, que é um Sérgio 
Milliet, um Luis da Câmara Cascudo, José Lins do Rego, Oton M. Garcia, ou Aníbal M. Machado, os descobridores do poeta durante o conflito mundial, Whitman é bardo "bíblico e profético," em quem "a plenitude da vida se afirmou mais completa e constantemente; é a voz do "solidarismo humano" que fez esta afirmação genial ; "todo aquêle que anda duzentos metros sem simpatia acompanha os seus próprios funerais revestido de sua mortalha ;" é o cantor da mediania, da "divina mediania," que admirava no povo a sua "capacidade de grandeza histórica;" Whitman é, finalmente, a voz da América que diz que "antes de mais nada é preciso respeitar a vida" — grande lição que é "a razão pela qual dêste continente não sairá nenhuma doutrina devastadora."

Já comentei o atraso com que o brasileiro traduziu Whitman, a. primeira versão que conheço sendo a publicada em 1942-43. E até hoje Whitman não encontraria siquer meia dúzia de poetas brasileiros que ousassem transportar "aquela orquestração fremente e sonora" para o português. Talvez a razẩo seja que outros concordam com o foclorista natalense Luis da Câmara Cascudo: "Um Whitman traduzido é uma diminuição infalivel" 78 Qualquer que seja no futuro a opinião sôbre o valor das traduções de Mário D. Ferreira Santos, Luis da Câmara Cascudo e Oswaldino Marques principalmente, ninguém jamais poderá negar-lhes a honra de terem sido os pioneiros na divulgação de. Whitman no Brasil. Graças a devoção dêstes, o Brasil encontra-se agora de portas abertas, atento ao seu convite e à sua mensagem:

Não me fecheis as vossas portas, orgulhosas bibliotecas,

Porque aquilo que estava faltando nas vossas abarrotadas estantes apesar de insistentemente procurado, eu trago.

Ao voltar da guerra um livro escreví.

As palavras de meu livio -.. nada; sua intenção - tudo.

Un livro único, sem nenhum vínculo com os demais nem percebido pelo intelecto.

Mas os vossos profundos alicerces, o'bibliotecas, abalar se-ão a cada uma de suas páginas. 79

Aparências whitmanianas, especialmente depois de lançado o Modernismo em 1922, são fácilmente descobertas na obra dos poetas brasileiros que tentam definir a sua terra e cantar o Novo Mundo. Vejam-se êstes versos con que termina o manifesto da nova estética 
modernista, estampado no primeiro número da revista do grupo "Festa," lançada no Rio em 1923 e encabeçada por Tasso da Silveira e Andrade Muricy. Possuem o sentido "total" de Whitman e dêle parecem tèr sido tirados na integra:

"Nosotros tenemos la comprensión nítida de este momento.

E1 arte es siempre el primero que habla para anunciar

lo que vendrá.

$\mathrm{E}$ l arte de este momento es un canto de alegría,

una reiniciación de la esperanza,

una promesa de esplendor.

Pasó el profundo desconsuelo romántico.

Pasó el estéril escepticismo parnasiano.

Pasó la angustia de las incertidumbres simbolistas.

El artista canta ahora la realidad total:

la del cuerpo y la del espíritu,

la de la naturaleza y la del sueño,

la del hombre y la de Dios.

$Y$ la canta, porque la percibe y comprende

en toda su múltiple belleza,

en su profundidad e infinitud.

$\mathrm{Y}$ por eso su canto

está hecho de inteligencia y de instinto

-porque también debe ser total-

y está hecho de ritmos libres

elásticos y ágiles como músculos de atletas,

veloces y altos como sutilísimos pensamientos.

Y sobre todo, palpitantes

del triunfo interior

que nace de las adivinaciones maravillosas...

$\mathrm{E} 1$ arte volvió a tener los ojos adolescentes

y se encantó nuevamente con la vida:

Todos los hombres lo acompañarán." 80

De tôdas as vozes modernistas nenhuma se assemelha mais a Whitman do que a voz de quem foi um dos chefes' dêsse movimento emancipador, o poeta carioca Ronald de Carvalho, cuja brilhante carreira foi cortada em pleno viço no ano de 1935, aos 42 anos de idade. $\mathrm{O}$ poeta e crítico uruguaio Gastón Figueira é de opinião que o belo poema Tôda a América deveria ser considerado, senão em ordem cronológica, indiscutivelmente em estética, "el primer poema continental." 81 Tudo nêsse livro que canta a "alegria de criar o caminho com a planta do pé" revela a influência direta e inegável de Leaves 
of grass. Falam bem claramente êstes versos finais do poema intitulado "Brasil":

Eu ouço todo o Brasil cantando, zumbindo, gritando, vociferando!

Redes que se balançam,

sereias que apitam,

usinas que rangem, martelam, arfam, estridulam, ululam e roncam,

tubos que esplodem,

guindastes que giram,

rodas que batem,

trilhos que trepidam,

rumor de coxilhas e planaltos, campainhas, relinchos, aboiados e mugidos,

repiques de sinos, estouros de foguetes, Ouro-Prêto, Bahia, Congonhas, Sabará,

vaias de Bolsas empinando números como papagaios, tumulto de ruas que saracoteiam sob arranha-céus, vozes de tôdas as raças que a maresia dos pôrtos joga no sertão!

Nesta hora de sol puro eu ouço o Brasil.

Tôdas as tuas conversas, pátria morena, correm pelo ar...

a conversa dos fazendeiros nos cafezais,

a conversa dos mineiros nas galerias de ouro,

a* conversa dos operários nos fornos de aço,

a conversa dos garimpeiros, peneirando as batéias,

a conversa dos coroneis nas varandas das roças...

Mas o que eu ouço, antes de tudo, nesta hora de sol puro

palmas paradas

pedras polidas

claridades

brilhos

faíscas

cintilações

é o canto dos teus berços, Brasil, de todos êsses teus berços, onde dorme, com a boca escorrendo leite, moreno, confiante,

o homem de amanhâ! 82

Porém, há críticos que negariam a Ronald de Carvalho o título de "Whitman do Brasil." Para Pompeu de Sousa, por exemplo, o 
verdadeiro Ronald é o poeta dos Epigramas irônicos e sentimentais, tão antípodas de Whitman e do Leaves of grass. Considera "superficial" e "de periferia" a assemelhação de Ronald a Whitman. O máximo que conseguiu Ronald foi "uma cópia dos processos, uma reprodução da fórmula da receita aprendida, jamais apreendida: tantas colheres de farinha de trigo, tantas de fermento, uma pitada de sal, batesse até levantar bolha, forno brando, etc." Chega a uma conclusão ainda mais severa: "Lendo-se o Ronald de 'Tôda a América' sente-se alguma coisa de Whitman: os assuntos, as comparações, o jeito de dizer as coisas, até os cacoetes, sobretudo os cacoetes, que no original são também grandeza e na cópia são apenas cacoetes mesmo. Mas a coisa é tão externa, tão exterior, tão ostensiva, tão amaneirada, que a impressão é a de que o 'cenário' whitmaniano foi convertido em cenografia de papelão e tinta para uso em apoteose de revista da praça 'Tiradentes." 83 Menos severa e mais justa em nosso parecer é a posição que toma Aníbal M. Machado. Este opina que Ronald abarcou os temas whitmanianos e fê-lo "com incontestável arte e inteligência, num belo ritmo largo." Mas confessa que "fáltou-lhe o essencial: o instinto, a brutalidade e a inocência do verdadeiro cantor da América. Teve a compreensão literária da obra, não o sentido cósmico de sua substância ..." 84

Felipe d'Oliveira (1891-1933) é outro reconhecido discípulo de Walt no Brasil. Os assuntos, a técnica, a exaltação lírico-épica da sua obra denunciam igual propósitó de assemelhar-se a Whitman, contemporâneamente com Ronald. Felipe tinha a mesma formação modernista. Ele também aspirava naquela época ser a voz da raça que brotava, "o brado que irmana." "Para João Daudt d'Oliveira, seu "irmão pelo sangue, pelo coração e pelo espírito," 85 a voz que estava vibrando em todo o Brasil nos primeiros anos do último conflito mundial era a voz mesma de Felipe que já en 1927 cantava assim no "Magnificat":

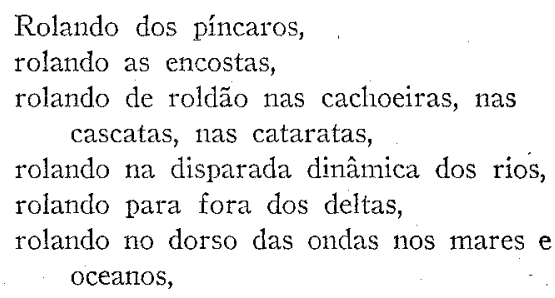




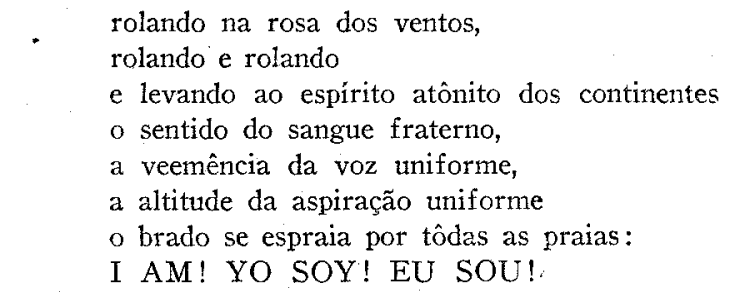

E por último, incumbe-me ainda referir-me a outros entre os poetas do mesmo movimento modernista que, sem haver procurado abertamente a Walt, têm se revelado espíritos sensiveis à sua estética. A pesar do ângulo de observação poética de Augusto Frederico Schmidt ser quase oposto ao de Whitman, Pompeu de Sousa descobre na poesia do bardo carioca "o mesmo ritmo largo ... a mesma capacidade de renovar os vocábulos, principalmente os adjetivos..., extraindo dêles sentidos inesperados e insuspeitados, sentidos e valores novos que com palavras novas não seriam possíveis." Assim, enquanto para êle a assemelhação de Ronald de Carvalho é apenas formal, a semelhança de Schmidt é substancial, auténtica, "resultante de uma consanguineidade legítima: a que decorre de uma origem, uma paternidade comun." Esta paternidade comun reside na Biblia, "de onde ambos nasceram poéticamente, embora $O$ americano não the seguisse os temas, continuando-lhe porém as formas com uma autenticidade de 'novíssimo testamento': o brasileiro conservando-lhe vários dos temas, embora não the reproduzindo com tanta perfeição a forma." 86

Não são precisas mais provas da grande admiração do poeta e crítico paulista Sérgio Milliet por Whitman, do que o seu ensaio inspirado e edificante intitulado "Walt Whitman, poeta da América." 87 Pode-se negar que esta admiração seja produto direto de fortes impulsos whitmanianos sôbre uma alma receptiva e fraternal? Não nos surpreende, pois, que Sérgio cante o seu desejo de ser livre - "sem submissão nem servilismo":

\footnotetext{
As árvores hão de mostrar-me a estrada

e os rios matar-me a sêde

e o mar embalar-me as máguas

e serei livre e louco como o vento.
}

nem que se esforçe em compreender a mensagem da voz profunda do mundo: 
Oh poeta da minha terra abre os braços para que venha a ti a voz profunda do mundo.

Nêle, como em Whitman, encontramos "o mesmo anseio e o mesmo espírito de humana compreensividade. Daí o poeta paulista fazer o apêlo em que ressoam tôdas as vozes perdidas entre o céu e a terra: 'Oh poeta canta o canto da libertação!'" ss

Em relação à possivel influência exercida no Brasil por outros de nossos grandes escritores e pensadores do século passado, não posso passar em silêncio o comentário de Fernando Tude de Souza em que afirma que o nosso célebre educador Horace Mann também teve no Brasil um admirador igual em estatura ao colosso argentino Sarmiento. Aparece num artigo intitulado "Horace Mann: $\mathrm{O}$ apóstolo da educação popular," escrito em homenagem ao $150^{\circ}$ aniversário do nascimento do "educador que pode ser apontado como o maior esteio da democracia." 89 Refletindo um pouco sôbre a vida dinámica e a ideologia liberal e progressista do grande homem de estado e escritor que foi Ruy Barbosa, é fácil concluir que êste bem pode ter sofrido "marcante influência de Horace Mann ..."

$\mathrm{E}$, finalmente, é Putnam quem chama a nossa atenção sôbre o fato de que a célebre autobiografia, Minha formação, de outro grande publicista brasileiro, Joaquim Nábuco, faz lembrar a Henry Adams. ${ }^{90}$

Voltemos uma vez mais ao momento atual, convencidos de que, embora rápido e superficial êste estudo que fizemos sôbre a fortuna de nossas letras no Brasil, e forçoso concluir que o impacto delas não foi nunca fator determinante no desenvolvimento literário daquêle país. Certos livros - A cabana do pai Tomaz- e certos escritores - Cooper, Longfellow, Poe, Whitman, tiveram influência marcante sôbre determinados momentos históricos e figuras literárias, mas nem em casos como êsses comparável à influência e à voga de um Poe, ou Longfellow, ou Whitman no mundo espanhol.

Seria difícil, senão impossível, tentar avaliar no momento o impacto de tantos livros norteamericanos traduzidos para o português nos últimos vinte anos, sôbre os escritores da chamada Geração de 1930 para cá. Ao falarmos de algumas destas obras traduzidas e dos próprios tradutores, insinuamos, porém, que o fato em si dêles -alguns mesmo escritores proeminentes- evidenciarem forte interesse em certas obras e em certos autores norteamericanos, pareceria pro- 
var afinidades espirituais e paralelismo literário pelo menos entre diversos escritores contemporâneos dos dois países. Tais paralelismos, por exemplo, são evidentes entre o grupo nordestino do Brasil e os nossos romancistas da categoria de Steinbeck et al. E é indiscutível que entre êles existe uma marcada afinidade estética e ideológica. Os críticos e o leitor em geral não vacilam em fazer tais comparações. Veja-se o que diz nêsse sentido um crítico tão autorizado como Samtuel Putnam na sua análise de $O$ resto é silêncio de Érico Veríssimo:

"Some have compared him to Thornton Wilder, and $O$ resto $e ́$ silêncio has even been seen as a sort of Bridge of San Luis Rey, set in Porto Alegre." 91

Ou vejam-se, finalmente, estas palavras com que Lúcia Miguel Pereira conclue seu luminoso ensaio:

"Mas não é o humanismo, não é a estética que preocupam agora os americanos, que dominam a sua literatura.

'E' a humanização, humanização da cultura, humanização da sociedade. Humanização que acarreta uma impureza, uma mistura perturbadora de criação do ponto de vista artístico. O escritor que se volta para o mundo, para a sociedade, não pode realizar a pura obra de arte, que exige silêncio e recolhimento, que se cresta ao contato ardente e rude da realidade.

“Também aquí a mesma impureza poderá ser apontada, no movimento dos últimos anos, talvez o mais importante da literatura brasileira, justamente porque tem êsse mesmo sentido de busca, de inquérito, de interrogação. De superposição dos elementos humanos aos estéticos.

"No nosso mundo deshumano, é essa a mensagem da América, a mensagem do continente onde a vida pode ainda ser altiva e livre." 92

O que é fundamental e resta por afirmar, com convicção e prazer, è que ao atingirem ambos países à maturidade literária e cultural, tais afinidades e paralelismos artísticos, que são como outro testemunho patente da amizade Brasil-Estados Unidos, prometem ainda melhor compreensão e mais profundas aproximações espirituais no futuro.

JOHN E. ENGLERIRK, Tulane University, New Orleans, La. 
$\mathrm{NOT}$ A S

II

24 Em português a mais extensa nota crítica e biográfica que conheço sôbre Longfellow é da pena de Xavier da Cunha e se encontra no estudo "Duas palavras de introdução sôbre a literatura americana." Este estudo, datado em Lisboa de 26 de outubro de 1879 , serve como prólogo para a tradução literal e muito elogiada de Evangelina feita por Miguel Street de Arriaga. Tanto a tradução como o estudo deveriam ter sido muito divulgados no Brasil, dêles existindo quatro exemplares na Biblioteca Pública da Bahia, por exemplo. É interessante notar o que da Cunha diz com respeito à presênça de nossa literatura em Portugal. Cooper, Poe, Irving, e "sobretudo o livro magnífico em que a talentosa Beecher Stowe arvorou a nobre propaganda contra os horrores da escravatura" é tudo o que lá se conhecia de nossas letras naquela época, e isto através de traduções francesas nem sempre bem feitas. Para êle os dois grandes poetas americanos são Bryant e Longfellow. Admite que Poe também é bom poeta, mas considera-o melhor prosista. Logo fala com amor da vida e da personalidade de Longfellow, terminando com a seguinte apreciação de sua individualidade poética: "Analisada no conjunto das suas mais primorosas produções, a individualidade poética de Longfellow engloba em si um mixto indefinivel e delicioso de Byron e de Tennyson, com as doçuras de Lamartine e por vêzes os arrôjos de Victor Hugo, perfumado tudo isto por um não-sei-que da poesia de Ossian!" p. LVII.

25 "Notes on Longfellow in Spanish America," Hispania, xxv, 3, outubro de 1942, pp. 295-308.

26 Obra citada, p. 298. Outro dado interessante relativo a Longfellow como poeta de textos escolares é o fornecido pelo tradutor de Evangelina, em edição publicada em São Paulo no ano 1884. Antônio P. d'Albuquerque era estudante do 3o ano jurídico da Faculdade de São Paulo. No prólogo à sua tradução literàl e anotada — anotações raras sôbre a linguagem e a sintaxe inglesas - diz que foi levado a fazer a tradução, em prosa, pela vontade que sempre teve de "coadjuvar os estudantes de inglês."

27 Outra vez é o mesmo Tobias Barreto que quer destruir outro mito de seu tempo. Veja-se o seu comentário sôbre a dedicatória no volume do Dr. José Soriano de Souza, Lições de filosofia elementar, em que o autor elogia D. Pedro II como "príncipe não só pelo sangue, pelo cetro, mas também pelas letras." Diz Tobias Barreto: "O principado literário do Sr. D. Pedro II, até nos domínios da filosofia, a cujo estudo não consta que tenha consagrado tempo algum de sua régia vida, é cousa que geralmente ainda se ignorava. Graças, porém, ao Dr. Soriano, fica sendo, d'ora avante, verdade adquirida, ponto de fé inabalável da ortodoxia monárquica. Além disso, bem se pode de ante- 
mão ajuizar da ordem de idéias de um homem de hoje, para quem existem principes pelo sangue." Vários escritos, p. 333.

28 V. Poesias completas de Pedro II, Guanabara, 1932, pp. 109-117.

29 Provavelmente a tradução em que colaboraram o chileno Carlos Morla Vicuña e o colombíano Rafael Pombo, que é a primeira tradução do poema para o espanhol, publicada em New York em 1871. Não é muito provável que a tradução de José Toribio Medina, publicada em Santiago em 1874, já tivesse chegado às mãos do Barão no ano em que publicara a sua no Rio.

30 Havia pelo menos quatro diferentes traduções italianas do poema anteriores a 1874, que são: Evangelina. Firenze, Felice Le Monnier, 1856. Trad. Pietro Rotondi; ibid., 1867; (fragmento), Canti di Roma antica di T. B. Macaulay e. Poesie sulla schiavitú e frammenti di E. W. Longfellow. Firenze, Successori Le Monnier, 1869. Trad. Louisa Grace Bartolini; - Firenze (1870 ?). Trad. Andrea Maffei; - Verona, 1873. Trad. Carolo Faccioli; - 2 ed. 1878. Com a exceção das traduções de Andrea Maffei e de Carolo Faccioli (primeira edição), há cópias destas na Longfellow House, Cambridge, Massachusetts. Devo estas e outras informações sôbre. Longfellow à cortesia do profesor Henry Wadsworth Longfellow Dana, neto do poeta.

31 A poesia da época, que é farta em citações, alusões, e reminiscências de Longfellow, denuncia às vêzes visível semelhança, às vêzes consanguineidade estética. Veja-se, por exemplo, o poema "Prelúdio" de Machado de Assis (Poesias, Jackson, 1944, pp. 193-194), que é encabeçado por êstes versos do poeta norteamericano:

". . . land of dreams...

... land of song."

32 Parece que Araripe Júnior escreveu outro trabalho sôbre Poe de que não tenho conhecimento. V. Agrippino Grieco. "Edgar Allan Poe," Estrangeiros, Rio, Ariel Edit., s. d. (1933 ?), p. 296.

33 Lanterna verde, 7, agôsto de 1943, pp. 23-25.

34 "Atitude oposta de Edgar Allan Poè e Walt Whitman em face do Não Ser," Lanterna verde, 7, agôsto de 1943, pp. 79-96.

35 "Divagações sôbre Edgar Poe," Correio da manhã (Rio), 28 de outubro de 1945.

36 "Edgar Poe," Ribeu, In, 6, setembro de 1944, pp. 68-76.

37 "Edgar Poe - anti-romântico." Ribeu, Irr, 7, janeiro de 1945, pp. 25-31.

38 Obra citada.

39 A atitude do crítico contra o nosso país — só dos tempos de Poe, ou de hoje também?- perde a fôrça pela própria repetição de apartes cujo teor 
soa como crítica estéril. Custa acreditar que um Grieco insista no velho ritornelo de "país de insaciáveis devoradores de dólares," "... tôda a beleza de um país sem beleza," e assim por adiante.

40 Poesia e prosa. Obras completas. Globo, 1944, p. 10.

41 Alguém (Peixoto ?) referiu-se a uma tradução feita por Anthero de Quental. Desta não tenho outras informações ou outra referência. E possível que o mesmo pensasse num poema de Quental intitulado "Do inglês de Edgar Poe," datado de 1864, e publicado em Primaveras românticas (Versos dos vinte anos - 1861-1864). V. a terceira edição, Coimbra, Imprensa da Universidade, 1926, pp. 129-131. Mas não é êle uma tradução do "Corvo;" inspirado em Poe, contem elementos de várias poesias do mesmo, principalmente do "Corvo" e de "Annabel Lee."

42 João Köpke, do Rio, foi Diretor de Educação durante muitos anos, e autor de vários livros escolares.

43 Obra citada:

44 As modernas correntes estéticas na literatura brasileira. Garnier, 1907, p. 70 .

45 Obra citada.

46 . Obra citada.

47 Marvelous journey, pp. 118-119. Baseándose em Peixoto ("American social and literary influences in Brasil." V. a nota 19 dêste estudo, Putnam afirma que "Poe none the less did have a certain direct influence upon Azevedo and his fellow bards, for the author of 'The Raven' and the Tales of the Grotesque and Arabesque was well known to Brazilians of this period... an Alvares de Azevedo and a Machado de Assis felt for Poe much the same admiration that Baudelaire did."

48 Nǫ̧óes de história da literatura brasileira, p. 296-299.

49 V. o meu livro Edgar Allan Poe in Hispanic literature, New York, Instituto de las Españas, 1934.

50 Evolução da poesia brasileira. 3 ed., Olympio, 1947, pp. 29-31.

51 V. Poesias escolhidas. Civilização brasileira, 1933, pp. 87-90.

52 Goldberg, obra citada, pp. 254, 256.

53 Obra citada, D. 65.

54 V. Poesias inéditas. Rio, Almeida Marques \& Cia., 1934.

55 Poemas escolhidos. Rio, Waissman, Reis, 1931, pp. 31-33.

56 Evolução da poesia brasileira, pp. 181-182. 
57 Afrânio Peixoto. Obra citada.

58 Estudos. Rio, 1929 , p. 110.

59 V. acima, pp. 10-11.

60 Loc. cit.

61 Estedos alemães. Rio, Laemmert, 1892, p. 154.

62 Ibid., p. 238.

63 Ibid., p. 51.

64 As modernas correntes estéticas na literatura brasileira, pp. 198-199.

65 Ibid., p. 184.

66 Ibid., p. 211.

67 Ibid., p. 242.

68 Noções de história da literatura brasileira, pp. 298-299.

69 V. os meus artigos "Notes on Whitman in Spanish America," Hispanic review, vI, 2, abril de 1938, pp. 133-138, e "Whitman y el anti-modernismo," Revista iberoamericana, outubro de 1947, pp. 39-52.

70 V. o que diz Sérgio Milliet em relação a êste ponto: "Haveria um estudo a fazer-se acerca da influência de Whitman sôbre a poesia européia $e$, através desta, sôbre a da América Latina: mas a dificuldade encontrada na consulta das obras poéticas dêstes últimos cincoenta anos torna difícil senão impossível tal tentativa entre nos." "Walt Whitman, poeta da América," Lanterna verde, 7, agôsto de 1943 , p. 140.

71 Éstudos, p. 112.

72 V. Gastón Figueira. "Visión de la nueva poesía del Brasil", Revista iberoamericana, vir, 13 , novembro de 1943 , pp. $85,87$.

“El 'Psalmo a la raza venidera' es una de las más acabadas realizaciones de este poeta. En él - como en algunas de las más originales páginas de Pádua de Almeida - el lírico se une al pensador, con algo de profeta... y aunque, quizá se halle a veces cierta afinidad con Walt Whitman, puede afirmarse también que los dos autores brasileños... se expresan más musical y sutilmente, sin perder su brío vital..."

73 Ibid:, p. 94.

"Poesia del hombre... nos trae la vivencia de un poeta trascendente y vigoroso, con algo de Walt Whitman y Paul Claudel, en su ritmo sinfónico, en su acento profético, en su sentido cósmico." 
74 V. Gastón Figueira. Poesia brasileña contemporánea (1920-1946), Montevideo, Instituto de Cultura Uruguayo-Brasileño, 1947, p. 123.

"Monteiro Lobato ha designado a este poeta como 'el Whitman sudamericano,' título justo desde cierto punto de vista. A veces... evoca igualmente a Langston Hughes. Camargo Guarnieri no dice sus dolores puramente personales. Lo que le conmueve es la mulfitud humana ávida y dolorida. Ciudadano del mundo, no es ajeno a un auténtico americanismo. Su orbe poético logra su mensaje, cuando Guarnieri lo refleja con sentido místico-social, con vocablos sencillos, humildes."

75 A primeira de que eu tenho conhecimento ê a do poema "A song of the rolling earth," por Bezerra de Freitas e Octávio Azevedo, publicada em Poetas norteamericanos, Rio, BIPA, 1943, mas que tera sido publicada antes -em 1942 ? - em $O$ cruzeiro do Rio.

76 Há quem afirme que foi Tobias Barreto o primeiro a referir-se a Whitman, no Brasil, lá por 1880. Não me foi possível verificar tal. Que eu saiba, a única referência a Walt feita por Barreto aparece no ensaio "Nota sôbre a literatura da América do Norte," (Vários escritos, pp. 277-280), datada de 1886.

77. Publicado primeiro pelo Jornal do Rio duranté maio e junho de 1946.

78 “Acta diurna," A república (Nata1), 18 de abril de 1945.

79 "Não me fecheis as vossas portas" ("Shut not your doors"). Trad. Oswaldino Marques.

80 Gastón Figueira. Poesia brasileña contemporánea (1920-46), pp. 18-19. Não me foi possível consultar o original. Esta tradução espanhola é do poeta e ensaista paraguaio, Leopoldo Ramos Giménez. Segundo Figueira, o autor do manifesto - publicado anônimo- e, em toda probabilidade, Tasso da Silveira.

81 V. a justa e acertada comparação que fạ Figueira entre Tôda a América do brasileiro e Alma América do peruano José Santos Chocano, em Poesía brasileña contemporánea (1920-1946), p. 48.

82 Tôda a América. Rio, Pimenta de Mello e Cia., 1926.

83 "Notícia geral sôbre Thornton Wilder," Correio da manhã (Rio), 23 de dezembro de 1946.

84 "Walt Whitman," O jornal (Rio), 2 de junho de 1946.

85 "O Pan-Americanismo realizado," Lanterna verde, 7, agôsto de 1943, pp. $54-58$.

86 Obra citada.

87 Lanterna verde, 7, agôsto de 1943, pp. 140-146. 
$Y$

88 V. Tito Lívio Ferreira. "Aspectos culturais da poesia brasileira," Boletim bibliográfico (São Paulo), 10, 1947, pp. 47-66.

89 O jornal (Rio), 12 de maio de 1946.

90 Marvelous journey, p. 200. Veja-se também Lúcia Miguel Pereira, obra citada, p. 18: “... nosso Joaquim Nabuco, com quem há uns longes de semelhança em Henry Adams."

91 "Brazilian literature," Handbook of Latin American studies, 1943, p. 408.

92 Ensaio de interpretação da literatura norteamericana, pp. 31-32. 
